\title{
ISTRAŽIVAČKI PODACI I VISOKOŠKOLSKE KNJIŽNICE
}

\author{
RESEARCH DATA AND ACADEMIC LIBRARIES
}

Irena Kranjec

Filozofski fakultet Zagreb, Knjižnica

ikranjec@ffzg.hr

Marijana Glavica

Filozofski fakultet Zagreb, Knjižnica

mglavica@ffzg.hr

Alen Vodopijevec

Centar za znanstvene informacije Instituta Ruđer Bošković alen@irb.hr

UDK / UDC [027.7:027.021]:[ 025.5: 004.77]

Stručni rad / Profesional paper

Primljeno / Received: 11. 4. 2018.

Prihvaćeno / Accepted: 2. 7. 2018.

\section{Sažetak}

Cilj. U radu se govori o ulozi visokoškolskih knjižnica u kontekstu otvorene znanosti, posebno u razvoju usluga podrške istraživačima, nastavnicima i studentima pri upravljanju i objavljivanju te ponovnom korištenju istraživačkih podataka. S obzirom na to da se istraživački podaci u knjižnicama mogu smatrati novom vrstom građe, iznose se postojeće definicije pojmova koji se odnose na istraživačke podatke te se razmatra koliko se usluge koje se tiču istraživačkih podataka mogu smatrati proširenjem tradicionalnih knjižničnih usluga, a u kolikoj su to mjeri sasvim nove usluge koje zahtijevaju i nove vještine i znanja.

Pristup. Proučavanje relevantne literature i dobrih praksi pružanja usluga koje se odnose na istraživačke podatke u visokoškolskim knjižnicama.

Vjesnik bibliotekara Hrvatske 61, 1(2018), 611-626

ISSN 0507-1925

(C) VBH 2018. 
Rezultati. Visokoškolske knjižnice, prateći promjene u znanstvenom okruženju te nove potrebe i zahtjeve svojih korisnika, trebale bi razvijati nove usluge podrške u procesima upravljanja i korištenja istraživačkim podacima. Neke od tih usluga jednostavno su proširenje uobičajenih zadaća informacijske službe na podatke kao vrstu građe (npr. tematska pretraživanja, informacije o citiranju), dok je za druge potrebno razvijati nove vještine i znanja knjižničara. Također je neophodna suradnja unutar knjižnice i s drugim službama u vlastitoj ustanovi, kao i s drugim ustanovama koje se bave istraživačkim podacima, naročito s arhivima podatka.

Praktična primjena. Prema preporukama iznesenim u radu, visokoškolske knjižnice mogu u svoje strategije, planove i prakse uvrstiti i neke od usluga koje se tiču istraživačkih podataka, ovisno o potrebama i raspoloživim resursima.

Ključne riječi: istraživački podaci, plan upravljanja podacima, usluge koje se odnose na istraživačke podatke, upravljanje istraživačkim podacima, visokoškolske knjižnice

\section{Abstract}

Purpose. The paper deals with the role of academic libraries in the context of open science, especially in supporting researchers, faculty and students in the research data management process, publishing and sharing research data. It examines research data as a new library material, the features and differences from the "traditional" library materials and services, as well as new skills and knowledge needed for research data services.

Approach. An overview is given of scientific and professional papers and examples of good practice regarding scientific data services in academic libraries.

Findings. Academic libraries should respond to the rapid changes in the scientific landscape and to the new needs of their users by developing research data services. Some of these services could be considered as expansion of the existing information services (for example searching and finding the resources and also citing of the research data sets), but in most cases this kind of services demands new skills and knowledge. Furthermore, the cooperation among library staff is of vital importance for the high-quality research data services development, as well as the cooperation with other faculty departments and other institutions dealing with research data (especially research data archives).

Practical implications. Academic libraries can consider introducing research data services in their strategic plans, missions, and planned activities according to the recommendations presented in the paper.

Keywords: academic libraries, data management plan, research data, research data services, research data management 


\section{Uvod}

Osnovna uloga visokoškolske knjižnice nije samo podrška nastavnom procesu već i podrška znanosti i istraživanjima. Promjene u znanstvenoj komunikaciji, provođenju znanstvenih istraživanja i diseminaciji rezultata znanstvenog rada neminovno utječu na visokoškolske knjižnice, pa one moraju svoje uloge i zadatke prilagođavati novim očekivanjima i zahtjevima svojih korisnika.

Tehnološki napredak omogućio je veću interdisciplinarnu suradnju, kolaborativan rad i internacionalizaciju znanstvenih istraživanja, a omogućavanje pristupa izvornim istraživačkim podacima jedan je od temeljnih elemenata pokreta za otvaranjem znanosti. U prvim se inicijativama (Budimpeštanskoj inicijativi iz 2002. ${ }^{1}$ i Bethesdanskoj izjavi iz 2003. godine ${ }^{2}$ ) govorilo o otvorenom pristupu publikacijama, dok Berlinska deklaracija iz 2003. uključuje i istraživačke podatke:

„Doprinosi otvorenom pristupu uključuju izvorne znanstvene rezultate, neobrađene podatke i metapodatke, izvornike, digitalne predstavke slikovnih i grafičkih materijala i znanstvenu multimedijsku građu." ${ }^{\text {3 }}$

Istraživački podaci predstavljaju velik izazov za same istraživače jer je njihova produkcija sve veća i osvještava se njihov potencijal za ponovno korištenje, nova istraživanja, nastavne svrhe i sl. Kroz razne se istraživačke politike od istraživača sve češće zahtijeva i dugoročno čuvanje podataka radi ponovnog korištenja. Sve veći broj financijera uvjetuje potpore za istraživanja izradom plana upravljanja podacima (engl. Data Management Plan, DMP) u kojem se dokumentira postupanje s podacima za vrijeme projekta i nakon njega.

Znanost koja se temelji na otvorenim podacima i obveza upravljanja podacima za istraživače pred visokoškolske knjižnice postavlja izazov razvijanja novih usluga koje će se baviti istraživačkim podacima kao novim izvorom informacija za svoje korisnike. Iako se ovaj rad primarno bavi visokoškolskim knjižnicama, njegov sadržaj primjenjiv je i na neke specijalne, sveučilišne i općeznanstvene knjižnice, odnosno na sve knjižnice čiji su korisnici istraživači te koje se bave podrškom znanstvenom radu.

\footnotetext{
1 Budapest Open Access Initiative. 2002. [citirano: 2018-04-09]. Dostupno na: http://www.budapestopenaccessinitiative.org/read.

2 Bethesda Statement on Open Access Publishing. 2003.[citirano: 2018-04-09]. Dostupno na: http://legacy.earlham.edu/ peters/fos/bethesda.htm.

3 Berlinska deklaracija. 2003. [citirano: 2018-04-09]. Dostupno na: http://eprints.rclis.org/4571/1/ prijevod_berlinske_deklaracije.pdf.
} 


\section{Istraživački podaci}

Istraživački je podatak u najširem smislu svaka građa koja se koristi ili nastaje u procesu istraživačkog rada i na kojoj se temelje spoznaje do kojih se došlo u tom procesu. U Stručnom vodiču kroz upravljanje podacima koji potpisuje konzorcij CESSDA ERIC ${ }^{4}$ govori se o četiri različita načina gledanja na podatke: prema vrsti, prema formatu, prema veličini i složenosti te prema fazi istraživanja u kojoj nastaju (vidi tablicu $1 \mathrm{u}$ kojoj su sažeto prikazani ti pogledi zajedno s primjerima za podatke u području društvenih i srodnih znanosti koji se tamo navode). Takva podjela u skladu je s perspektivom u kojoj „sve manifestacije istraživačkih podataka treba aktivno držati pod kontrolom kako bi se postigla visoka kvaliteta podataka s potencijalom za ponovnu upotrebu“".

Tablica 1. Različiti načini gledanja na podatke s primjerima za podatke u društvenim i srodnim znanostima ${ }^{6}$

\begin{tabular}{|c|c|c|}
\hline \multirow[t]{3}{*}{ Prema vrsti } & Prema izvoru & $\begin{array}{l}\text { registri (administrativni, povijesni, rezultati } \\
\text { glasovanja, medicinski); postojeći istraživački } \\
\text { podaci; statistički podaci }\end{array}$ \\
\hline & $\begin{array}{l}\text { Prema fizičkom } \\
\text { obliku }\end{array}$ & $\begin{array}{l}\text { numerički, tekstni, slikovni, geoprostorni, } \\
\text { audio, video, softver }\end{array}$ \\
\hline & $\begin{array}{l}\text { Prema načinu } \\
\text { nastajanja }\end{array}$ & $\begin{array}{l}\text { elektronički dokumenti, tablice, bilješke } i \text { dnev- } \\
\text { nici iz laboratorija ili s terena, upitnici, tran- } \\
\text { skripti, kodne knjige, audiozapisi i videozapisi, } \\
\text { fotografije i film, rezultati ispitivanja, primjer- } \\
\text { ci vrste, uzorci, artefakti, sheme baza podata- } \\
\text { ka, sadržaj baza podataka, modeli, algoritmi } i \\
\text { skripte, hodogrami, standardni postupci i pro- } \\
\text { tokoli u radu, eksperimentalni rezultati, meta- } \\
\text { podaci i drugo, poput popisa literature ili elek- } \\
\text { troničke komunikacije }\end{array}$ \\
\hline $\begin{array}{l}\text { Prema } \\
\text { formatu } \\
\text { datoteke }\end{array}$ & \multicolumn{2}{|c|}{$\begin{array}{l}\text { statistički podaci - SPSS (.sav) ili STATA } \\
\text { filmovi - .mpg ili .avi } \\
\text { strukturirani podaci -.xml ili relacijska baza podataka } \\
\text { tekstni podaci -.docx, .pdf ili .rtf }\end{array}$} \\
\hline
\end{tabular}

${ }^{4}$ CESSDA ERIC. Expert tour guide to data management. [citirano: 2018-04-06]. Dostupno na: https://www.cessda.eu/Research-Infrastructure/Training/Expert-Tour-Guide-on-Data-Management.

5 CESSDA ERIC. Research data. // Expert tour guide to data management. [citirano: 2018-0406]. Dostupno na: https://www.cessda.eu/Research-Infrastructure/Training/Expert-Tour-Guide-on-Data-Management/1.-Plan/Research-data.

6 Isto. 


\begin{tabular}{|l|l|}
\hline $\begin{array}{l}\text { Prema } \\
\text { veličini i } \\
\text { složenosti }\end{array}$ & $\begin{array}{l}\text { prema veličini datoteke - mali ili veliki } \\
\text { prema sadržaju - jednostavni ili složeni }\end{array}$ \\
\hline $\begin{array}{l}\text { Prema fazi } \\
\text { istraživanja }\end{array}$ & sirovi, očišćeni, obrađeni, analizirani \\
\hline
\end{tabular}

Za brigu o istraživačkim podacima, njihovu pohranu, trajno očuvanje i osiguravanje pristupa više je razloga. Time se može povećati utjecaj znanstvenoistraživačkog rada, izbjegava se udvostručavanje financijskih troškova, vremena i truda, a pohranjeni i očuvani podaci mogu se koristiti za buduća nova istraživanja (sekundarne analize, komparativna istraživanja, validacija originalnih istraživanja) ili za podučavanje studenata. Kako bi se to postiglo, potrebno je razviti pouzdanu infrastrukturu koja će podržati cijeli životni ciklus podataka, na početku, tijekom istraživačkog projekta i nakon njega. Životni ciklus podataka počinje planiranjem i nastavlja se kroz prikupljanje ili generiranje podataka te njihovu obradu i analizu, a nakon toga podaci se mogu arhivirati i objaviti radi ponovnog korištenja, čime se ciklus zatvara i počinje novi, u koji sada ulaze cjeloviti podaci iz prethodnog istraživanja ili samo njihov dio. ${ }^{7}$ U svakoj fazi toga ciklusa potrebno je imati kontrolu, odnosno upravljati podacima.

Ključni elementi procesa upravljanja podacima jesu: način postupanja s podacima, organiziranje i strukturiranje podataka, jasno i detaljno dokumentiranje te planiranje dugoročne pohrane kako bi se podaci mogli ponovno koristiti. Plan upravljanja podacima formalni je dokument u kojem su opisani svi ti elementi i izrađuje se odmah, tj. u prvim fazama projekta. Kreiranje takva plana omogućava bolju pripremu aktivnosti, resursa (ljudi, opreme) i tehničke infrastrukture potrebne za njegovo provođenje. ${ }^{8}$ Upravljanje podacima obuhvaća mnoge postupke koji već jesu dio uobičajene istraživačke prakse, kao što su dokumentiranje metodologije istraživanja, postupaka i konteksta nastajanja podataka, zapisivanje podataka u računalne formate, organizacija podataka, kodiranje, kontrola konzistentnosti, anonimizacija i sl. No tu je obuhvaćen i niz postupaka kojima se istraživači dosad nisu toliko bavili, a radi se o uvjetima koje je potrebno osigurati u okolini u kojoj se potiče ponovno korištenje i dugoročna pohrana podataka, naprimjer formati podataka prikladni za dugoročno očuvanje, standardi za elemente metapodataka, sigurna pohrana i razmjena, reguliranje pristupa te specifični pravni i etički aspekti zaštite sudionika u istraživanju, licencije i druga autorsko-pravna pitanja.

\footnotetext{
${ }^{7}$ UK Data Service. Research data lifecycle. [citirano 2018-07-02]. Dostupno na: https://www. ukdataservice.ac.uk/manage-data/lifecycle.

8 Više o upravljanu podacima vidi u CESSDA ERIC. Expert tour guide to data management. [citirano: 2018-04-06]. Dostupno na: https://www.cessda.eu/Research-Infrastructure/Training/ Expert-Tour-Guide-on-Data-Management/6.-Archive-Publish/Data-publishing-routes.
} 
Arhiviranje i objava podataka također su dio upravljanja istraživačkim podacima i u toj domeni istraživači najčešće traže podršku stručnjaka specijaliziranih za podatke. Postoji više načina pohrane i objave podataka. To mogu biti institucijski repozitoriji, repozitoriji opće namjene ili repozitoriji specifični za domenu (tematski), a podatke je moguće objaviti i kao popratni materijal u časopisu. ${ }^{9}$ Jedna od prednosti pohrane u tematske repozitorije jest lakoća pronalaženja pohranjenog seta podataka budući da su takvi repozitoriji najčešće poznato mjesto istraživačima $u$ određenom području, što povećava potencijal za ponovno korištenje objavljenih podataka. Još važnije, takvi repozitoriji podržavaju specifične zahtjeve određenih znanstvenih područja ili interesa, što nas dovodi do još jednog kriterija razlikovanja repozitorija, odnosno ustanova koje se bave pohranom i diseminacijom, a to je razina i opseg usluga koje pružaju. Dok neki samo osiguravaju platformu za objavu s osnovnim setom metapodataka (najčešće institucijski i repozitoriji opće namjene) i ne rade selekciju podataka, drugi (najčešće tematski) grade takozvane pouzdane (engl. trusted) repozitorije koji su više usmjereni na osiguravanje dugoročne dostupnosti podataka visoke kvalitete i velikog potencijala za ponovno korištenje. To postižu selekcijom podataka, iscrpnim dokumentiranjem i upotrebom metapodataka koji obuhvaćaju sve bitne karakteristike i okolnosti nastajanja podataka u određenom području, korištenjem standardnih procedura za dugoročno očuvanje (npr. migracija formata) i mnogim drugim postupcima kojima se postiže lakoća pronalaženja, dostupnost, interoperabilnost i mogućnost ponovnog korištenja (FAIR-principi ${ }^{10}$ ). U području društvenih znanosti primjere takvih pouzdanih tematskih repozitorija u Europi možemo naći u arhivima podataka u Konzorciju europskih arhiva podataka za društvene znanosti (CESSDA - Consortium of European Social Science Data Archives $)^{11}$, a u SAD-u je najpoznatiji Inter-university Consortium for Political and Social Research (ICPSR). ${ }^{12}$ U arhiviranju i dijeljenju podataka, osim društvenih znanosti, prednjače i pojedine discipline poput meteorologije ${ }^{13} \mathrm{i}$ astronomije ${ }^{14}$ te uža

\footnotetext{
9 CESSDA ERIC. Data publishing routes. // Expert tour guide to data management. [citirano: 2018-04-06]. Dostupno na: https://www.cessda.eu/Research-Infrastructure/Training/Expert-Tour-Guide-on-Data-Management/6.-Archive-Publish/Data-publishing-routes.

${ }^{10}$ Wilkinson, M. D.; M. Dumontier; I. J. Aalsbersberg; G. Appleton; M. Axton; A. Baak; N. Blomberg, et al. The FAIR Guiding principles for scientific data management and stewardship. // Scientific Data 3(2016), 160018. DOI: http://dx.doi.org/10.1038/sdata.2016.18.

${ }^{11}$ CESSDA ERIC. [citirano: 2018-04-09]. Dostupno na: https://www.cessda.eu/.

12 Inter-university Consortium for Political and Social Research (ICPSR). [citirano: 2018-04-09]. Dostupno na: https://www.icpsr.umich.edu.

${ }_{13}$ Unidata: data services and tools for geoscience. [citirano: 2018-04-07]. Dostupno na: http:// www.unidata.ucar.edu/data/.

${ }^{14}$ Henneken, E. Unlocking and sharing data in astronomy. // Bulletin of the Association for Information science and technology 41, 48(2015), str. 40. [citirano: 2018-04-08]. Dostupno i na: https://asis.org/Bulletin/Apr-15/AprMay15_RDAP_Henneken.pdf.
} 
područja kao što je naprimjer genomika. ${ }^{15}$ Primjer repozitorija opće namjene jest digitalni repozitorij Zenodo ${ }^{16}$ nastao kroz OpenAIRE-projekte financirane od strane Europske komisije. Trenutno najpotpuniji registar repozitorija istraživačkih podataka jest „re3data“"17, registar koji omogućava prebiranje i pretraživanje više od 2000 zapisa o repozitorijima iz svih znanstvenih područja.

Sustavnom brigom o istraživačkim podacima sprečava se njihov trajni gubitak, što je čest slučaj kada oni, npr. nakon obrade, ostaju na lokalnim računalima istraživača, te se omogućava njihovo ponovno korištenje, što smanjuje troškove istraživanja, pa financijeri istraživanja sve veću važnost pridaju i ekonomskom utjecaju. Tako naprimjer Organizacija za ekonomsku suradnju i razvoj (engl. Organisation for Economic Cooperation and Development, OECD) navodi:

„Dijeljenje i otvoreni pristup javno financiranim istraživačkim podacima ne samo da pomaže maksimaliziranju istraživačkih potencijala novih digitalnih tehnologija i mreža već i osigurava veći povrat javnih investicija u istraživanje." ${ }^{18}$

Ponovno korištenje podrazumijeva i mogućnost provjeravanja rezultata originalnog istraživanja, što doprinosi kvaliteti i transparentnosti znanstvenog rada, a to je još jedan razlog zbog kojeg su financijeri istraživanja zainteresirani za tu tematiku. U okviru programa Europske unije za istraživanje i inovacije za razdoblje od 2014. do 2020. godine Obzor 2020 (engl. Horizon 2020), obvezan je otvoreni pristup recenziranim publikacijama nastalim u okviru projekata financiranih iz sredstava EU. ${ }^{19} \mathrm{U}$ okviru istog programa nakon provedenog pilota Otvoreni istraživački podaci (2014-2015) ${ }^{20}$ od početka 2017. godine obveza se odnosi na sva područja i sve projekte. ${ }^{21}$ Što se otvorenosti podataka tiče, Komisija snažno zagovara otvoreni pristup, no dopušta i izuzeće u slučajevima moguće komercijalizacije rezultata istraživanja, osjetljivih podataka ili ugrožavanja postizanja glavnog cilja istraživanja. ${ }^{22}$

15 National Human Genome Research Institute. [citirano: 2018-04-09]. Dostupno na: www.genome.gov.

16 Zenodo. [citirano: 2018-04-09]. Dostupno na: https://zenodo.org/.

17 re3data.org. [citirano: 2018-04-06]. Dostupno na: http://www.re3data.org/.

${ }_{18}$ OECD. Principles and guidelines for access to research data from public funding. OECD, 2007. [citirano: 2018-04-06]. Dostupno na: http://www.oecd.org/sti/sci-tech/38500813.pdf

19 Ministarstvo znanosti, obrazovanja i sporta i AMPEU. Što je Obzor 2020? [citirano: 2018-0406]. Dostupno na: http://www.obzor2020.hr/.

${ }^{20}$ OpenAire. Open Research Data Pilot. 2016. [citirano: 2018-04-06]. Dostupno na: https://www. openaire.eu/opendatapilot.

${ }^{21}$ European Commission, Directorate-General for Research \& Innovation. H2020 programme: guidelines to the rules on open access to scientific publications and open access to research data in Horizon 2020. [citirano: 2018-04-06]. Dostupno na: http://ec.europa.eu/research/participants/ data/ref/h2020/grants_manual/hi/oa_pilot/h2020-hi-oa-pilot-guide_en.pdf.

22 Isto, str. 8 


\section{Istraživački podaci kao vrsta građe u knjižnici}

Istraživački podaci po svojim se formalnim i sadržajnim karakteristikama razlikuju od znanstvenih publikacija, pa je ostvarivanje otvorenog pristupa podacima proces koji od svih sudionika u znanstvenim procesima zahtijeva dodatna znanja, napore i vrijeme. Nameće se pitanje zašto bi se knjižnice uključile u proces upravljanja istraživačkim podacima. Iz prethodno navedenog jasno je da znanstvenici, kao korisnici visokoškolskih knjižnica, imaju nove potrebe u kontekstu otvorene znanosti, novih tehnologija i zahtjeva koje pred njih postavljaju financijeri istraživanja. I financijeri knjižnica, tj. vladina tijela, uprave sveučilišta i fakulteta, imaju u svjetlu tih promjena nove zahtjeve i očekivanja od knjižnica. Žele li (p)ostati značajan čimbenik u tom promjenjivom digitalnom istraživačkom okružju, knjižnice se moraju znati prilagoditi promjenama. Vrijednost knjižnica dugo se mjerila veličinom i raznolikošću njihovih zbirki, a danas sve više prevladava mišljenje da se knjižnice trebaju vrednovati na temelju njihovih usluga ${ }^{23}$ te da se vrijednost knjižnice izražava kombinacijom financijske vrijednosti i njezina „utjecaja“ ${ }^{24}$ No odabir građe i izgradnja zbirki i dalje su važni ukoliko se želi pružiti usluga koja ima utjecaj. Sama zbirka bez usluge nije knjižnica, a pružanje usluga bez organizacije i kontrole nad zbirkama informacija tek je puko posredništvo. ${ }^{25}$

Promatramo li istraživačke podatke kao novu vrstu građe, treba utvrditi kako se oni uklapaju u tradicionalne knjižnične usluge i građu te u kojoj mjeri iskustvo knjižnica u odabiru, čuvanju i zaštiti građe, izradi metapodataka, pronalaženju i osiguravanju pristupa građi te održavanju digitalnih repozitorija može biti temelj za to da knjižnice postanu relevantne u procesu upravljanja podacima. ${ }^{26}$ Već $\mathrm{s}$ pojavom elektroničkih izvora, kao što su e-knjige i časopisi, u knjižnicama se dogodio pomak od nabave i dostave građe prema osiguravanju pristupa. Također, elektronička građa utjecala je na razvoj novih znanja i vještina knjižničara, npr. o autorsko-pravnim pitanjima, licencama, reguliranju prava pristupa, pretraživanju i diseminaciji elektroničkih izvora te novih usluga koje nude svojim korisnicima, kao što su radionice informacijske pismenosti, pretraživanja elektroničkih izvora, podrška u pohrani elektroničke građe i drugo.

Istraživački su podaci po mnogočemu različiti od klasičnih znanstvenih publikacija, bilo u tiskanom ili elektroničkom obliku. Bitna razlika odnosi se na načine identificiranja informacija za interpretaciju sadržaja i metapodatkovni opis. Za

\footnotetext{
${ }^{23}$ Geraci, D.; J. Jacobs; C. Humphrey. Data basics: an introductory text. 2012.Str. 7.2. DOI: http://dx.doi.org/10.7939/R3251FK8F.

${ }^{24}$ Association of College and Research Libraries. Value of academic libraries: a comprehensive research review and report. Researched by Megan Oakleaf. Chicago: Association of College and Research Libraries, 2010. [citirano 2018-06-10]. Dostupno na: http://www.ala.org/acrl/sites/ala. org.acrl/files/content/issues/value/val_report.pdf.

${ }^{25}$ Geraci, D.; J. Jacobs; C. Humphrey. Nav. dj., str. 7.2.

${ }^{26}$ Rice, R.; J. Southall. The data librarian's handbook. London: Facet Publishing, 2016. Str. 2.
} 
publikacije je lakše pronaći potrebne informacije jer ih je većina sadržana u samoj publikaciji, pa je ona kao takva samorazumljiva. Za razumijevanje podataka, osim datoteke s podacima, potrebna je i popratna dokumentacija kako bi se, između ostalog, otkrilo značenje varijabli i kodova, saznala jedinica mjerenja, način prikupljanja podataka i okolnosti u kojima su podaci nastali. Metapodatkovne opise za podatke i dokumentaciju specifičnu za pojedina znanstvena područja tek treba razviti u suradnji sa zajednicama istraživača, uzimajući u obzir svu raznolikost vrsta podataka, formata, veličine, kompleksnosti i faze istraživanja u kojoj podaci nastaju. Također, istraživački podaci često su specifični za manje grupe istraživača umjesto za cijelo znanstveno područje ili polje, pa se i procedure i alati za upravljanje podacima trebaju prilagođavati na toj razini.

\section{Razvoj usluga}

Izrada plana upravljanja podacima od istraživača zahtijeva i dodatno vrijeme, trud i novac, a objavljivanje i javna dostupnost istraživačkih podataka kod mnogih izazivaju pravne i etičke nedoumice. Uz otvoreni pristup istraživačkim podacima veže se još uvijek niz otvorenih pitanja ${ }^{27}$ o potrebama i specifičnostima različitih istraživačkih praksi, pravnim i etičkim pitanjima, citiranju podataka, tehničkoj infrastrukturi te poticanju objavljivanja i omogućavanja sekundarnog korištenja.

Stoga ne čudi što prema nekim istraživanjima ${ }^{28}$ među znanstvenicima postoji suzdržanost kada se radi o davanju istraživačkih podataka na korištenje drugima. Zbog toga im treba podrška, pa visokoškolske knjižnice ponajprije u tom smjeru mogu razvijati nove usluge. Prije svega, knjižničari specijalizirani za istraživačke podatke (engl. data librarians) trebaju kod istraživača podizati razinu osviještenosti o važnosti upravljanja podacima kako bi se arhiviranje, dugoročno očuvanje i ponovno korištenje usvojilo kao uobičajena istraživačka praksa. Osim toga, knjižničari mogu pružati informacijske ili savjetodavne usluge oko plana upravljanja podacima, metapodatkovnih standarda, citiranja podataka i slično ${ }^{29}$. Na tehničkoj razini $^{30}$, u slučaju da se radi o institucijskom repozitoriju, možemo govoriti o suradnji knjižničara s drugim službama, prije svega informatičkom, u osiguravanju

27 Linde, P.; M. Noorman; B.A. Wessels; T. Sveinsdottir. How can libraries and other academic stakeholders engage in making data open? // Information Services \& Use, 34(2014), str. 217. DOI: https://doi.org/10.3233/ISU-140741.

${ }^{28}$ Pampel, H. ; S. Dallmeier-Tiessen. Open research data: from vision to practice. // Opening science: the evolving guide on how the Web is changing research, collaboration and scholarly publishing / S. Bartling, S. Friesike [eds.]. Berlin: Springer, 2014. Str. 139-153. [citirano: 201804-06]. Dostupno na: http://book.openingscience.org/vision/open_research_data.html.

${ }_{29}$ Tenopir, C.; R.J. Sandusky; S. Allard; B. Birch. Research data management services in academic research libraries and perception of librarians. // Library \& Information Science Research 36, 2(2014), 84-90. DOI: https://dx.doi.org/10.1016/j.lisr.2013.11.003.

30 Isto. 
podrške pri pohrani i diseminaciji podataka (npr. uspostavljanje repozitorija, razvoj kataloga za pretraživanje podatka) te brizi o sadržaju repozitorija, što uključuje odabir i pripremu podataka za arhiviranje, opisivanje podataka metapodacima i drugo.

Analiza dviju studija o knjižničnim uslugama podrške upravljanju istraživačkim podacima (engl. Research Data Management Services, RDS) u knjižnicama SAD-a i Kanade Tenopira i suradnika ${ }^{31}$ pokazuje da te usluge nisu česta pojava u knjižnicama, ali su u mnogim knjižnicama u fazi planiranja. Tehnički vidovi tih usluga manje su zastupljeni od informacijskih i više se pružaju profesorima nego studentima. Voditelji knjižnica u većem postotku misle da zaposlenicima knjižnice pružaju mogućnosti za razvijanje vještina potrebnih za pružanje tih usluga nego što zaposlenici percipiraju da imaju mogućnosti za razvoj potrebnih vještina. Vrlo slični rezultati dobiveni su i istraživanjem provedenim u visokoškolskim knjižnicama u Europi. ${ }^{32}$ Knjižničarima je stoga potrebno pružiti više mogućnosti za razvijanje potrebnih vještina. ${ }^{33}$

Sudjelovanje knjižničara u procesu upravljanja istraživačkim podacima znači njihovo uključivanje $u$ istraživački proces puno ranije nego što je to slučaj $u$,tradicionalnom knjižničarstvu“ ${ }^{34}$ Knjižničari se više ne bave samo rezultatima istraživačkog rada u obliku objavljenih radova i publikacija, koje onda odabiru, nabavljaju, obrađuju, uključuju u svoj fond te ih čuvaju i osiguravaju pristup prema potrebama svojih korisnika, već se svojim uslugama uključuju već u pripremnu fazu istraživačkog procesa. Istraživački podaci od knjižničara zahtijevaju neka sasvim nova znanja i vještine. Prije svega, tu se misli na poznavanje metodologije istraživanja, instrumenata za prikupljanje podataka i softvera za analizu podataka te procedura i alata za upravljanje istraživačkim podacima. Pritom treba napomenuti kako se ne očekuje da sve te vještine i znanja ima samo jedan knjižničar, jer upravljanje istraživačkim podacima zahtijeva timski rad i suradnju kako unutar knjižnice tako i unutar šireg okruženja.

\footnotetext{
31 Isto, str. 88.

${ }^{32}$ Tenopir, C.; S. Talja; W. Horstmann; E. Late; D. Hughes; D. Pollock; B. Schmidt; L. Baird; R. J. Sandusky; S. Allard. Research data services in European academic research libraries. // LIBER Quarterly 27, 1(2017), 23-44. DOI: https://dx.doi.org/10.18352/lq.10180.

${ }^{33}$ Conrad, S.; Y. Shorish; A.L. Whitmire; P. Hswe. Building professional development opportunities in data services for academic librarians. // IFLA Journal 43, 1(2017), 65-80 .DOI: http:// dx.doi.org/10.1177/0340035216678237.

${ }^{34}$ Gold, A. Cyberinfrastructure, data, and libraries. Part 1: a cyberinfrastructure primer for librarians. // D-Lib Magazine 13, 9-10(2007). DOI:10.1045/september2007-gold-pt1 Vidi i Gold, A. Cyberinfrastructure, data, and libraries. Part 2: libraries and the data challenge: roles and actions for libraries. // D-Lib Magazine 13, 9-10(2007). DOI: http://dx.doi.org/10.1045/september2007-gold-pt2.
} 
Možemo govoriti o različitim modelima razvoja, odnosno razinama knjižničnih usluga koje se odnose na istraživačke podatke. ${ }^{35}$ Tako Flores i suradnici tvrde da tehnička podrška prilikom uspostavljanja institucijskih repozitorija istraživačkih podataka može biti dobra ideja za istraživanja i podatke koji ne ispunjavaju uvjete za pohranu u postojećim tematskim repozitorijima, no takvi repozitoriji ne bi trebali obuhvaćati sva istraživanja u svojoj zajednici, kao što je slučaj s institucijskim repozitorijima za pohranu znanstvenih radova i publikacija. ${ }^{36}$ Također smatraju da su knjižničari, s obzirom na svoja znanja o znanstvenoj metodologiji, diseminaciji znanja i informacija te suradnji i poznavanju glavnih dionika u procesu upravljanja istraživačkim podacima (vladinih tijela i drugih financijera, ustanova i odjela/službi unutar tih ustanova koje pružaju podršku istraživačkom procesu, uprava fakulteta i sveučilišta te istraživača) u dobroj poziciji da preuzmu koordinacijsku ulogu pri uvođenju sustava upravljanja podacima. U tom kontekstu koordinacija uvođenja i pružanja niza usluga podrazumijeva: ${ }^{37}$

- kontrolu pristupa i embarga (odgode pristupa)

- podizanje svijesti o važnosti upravljanja podacima i obvezama koje nameću financijeri

- osiguravanje trajnih identifikatora, uključujući digitalne identifikatore objekata - DOI (Digital Object Identifier) za setove podataka radi mogućnosti točnog citiranja podataka

- dokumentiranje podataka, tj. pomaganje znanstvenicima pri dokumentiraju na početku istraživanja uz poštivanje standarda struke

- osiguravanje potpore za izradu plana upravljanja podacima

- razvoj infrastrukture za pohranu i dostupnost podataka, npr. institucijski repozitorij podatka

- izradu smjernica vezanih uz intelektualno vlasništvo koje se odnose na istraživačke podatke

- savjete o odgovarajućim formatima podataka, priprema setova podataka za dugoročno očuvanje

- savjetovanje o pitanjima privatnosti i tajnosti pri upravljanju podacima

- pomoć pri pronalaženju odgovarajućeg repozitorija/arhiva

35 Cox, A.M.; M.A. Kennan; L. Lyon; S. Pinfield. Developments in research data management in academic libraries: towards an understanding of research data service maturity. // Journal of the Association for Information Science and Technology 68, 9(2017), 2182-2200. DOI: http://dx.doi. org/10.1002/asi.23781.

${ }^{36}$ Reeves Flores, J.; J.J. Brodeur; M. G. Daniels; N. Nicholls; E. Turnator. Libraries and the research data management landscape. // The process of discovery: the CLIR postdoctoral fellowship program and the future of the academy. / edtors J. . Maclachlan, E. A. Waraksa, C. Williford. Str. 92. [citirano: 2018-04-06]. Dostupno na: https://www.clir.org/wp-content/uploads/sites/9/RDM. pdf.

${ }^{37}$ Isto, str. 91. 
- organiziranje radionica i prezentiranje najboljih praksi u izradi planova upravljanja istraživačkim podacima

- promoviranje mehanizama za praćenje znanstvenog utjecaja dijeljenja podataka, preuzimanja, citiranja i sl.

- pomoć u povezivanju setova podatka s drugim rezultatima znanstvenog rada pomoću mehanizama povezanih podataka i citiranja.

Iz navedenog je razvidna potreba za suradnjom knjižnica s ostalim službama, kao što je računalni centar, te sa samim znanstvenicima pri uspostavljanju i uvođenju usluga koje se odnose na istraživačke podatke. ${ }^{38}$

Radna grupa Udruženja europskih istraživačkih knjižnica (engl. Association of European Research Libraries, AERL) za znanost i upravljanje istraživačkim podacima sastavila je deset preporuka za uspostavljanje procesa upravljanja istraživačkim podacima namijenjenih knjižnicama. ${ }^{39}$

1. Pružanje podrške istraživačima u procesu upravljanja istraživačkim podacima, uključujući i podršku pri izradi plana upravljanja istraživačkim podacima za istraživače koji apliciraju za dobivanje potpore za svoja istraživanja i savjete o autorskim pravima, te izrada edukacijskih materijala. Pomaganje nastavnicima oko planova upravljanja istraživačkim podacima i integracije upravljanja podacima u kurikulum.

2. Uključivanje u razvoj metapodataka i standarda za podatke i opisivanje podataka metapodacima.

3. Otvaranje radnog mjesta knjižničara specijaliziranog za istraživačke podatke i stjecanje pripadajućih stručnih vještina.

4. Aktivno sudjelovanje u razvoju politika ustanove o istraživačkim podacima, uključujući planiranje resursa. Podržavanje i usvajanje, gdje je moguće, politike otvorenih podatka u životnom ciklusu podataka.

5. Povezivanje i izgradnja partnerskih odnosa s istraživačima, istraživačkim grupama, arhivima podatka i podatkovnim centrima kako bi se ojačala interoperabilna infrastruktura za pristup, pronalaženje i dijeljenje podatka.

6. Podrška životnom ciklusu podataka kroz pružanje usluga pohrane, pronalaženja i osiguravanja trajnog pristupa.

7. Promoviranje citiranja istraživačkih podataka dodjeljivanjem trajnih identifikatora istraživačkim podacima.

\footnotetext{
${ }^{38}$ Geraci, D.; J. Jacobs; C. Humphrey. Nav. dj. Str. 2.3.

39 Association of European Research Libraries. Ten recommendations for libraries to get started with research data management: final report of the LIBER working group on e-science / research data management. 2012. Str. 1. [citirano: 2018-04-06]. Dostupno na: http://libereurope.eu/ wp-content/uploads/The\%20research\%20data\%20group\%202012\%20v7\%20final.pdf.
} 
8. Izrada kataloga podatka ustanove ili repozitorija istraživačkih podataka, ovisno o raspoloživoj infrastrukturi.

9. Uključivanje u procese upravljanja specifičnih predmetnih podataka.

10. Pružanje sigurne okoline za pohranu dinamičnih i statičnih podataka ili upućivanje na pouzdane pružatelje takvih usluga u suradnji s informatičkom službom ustanove $\mathrm{i} / \mathrm{ili}$ istraživanje mogućnosti pružanja usluga $u$ oblaku.

Te preporuke ne znače da sve knjižnice nužno trebaju pružati sve navedene usluge ni da ih trebaju uvesti istovremeno. Uvođenje tih usluga treba raditi planski, uvažavajući lokalne uvjete i resurse, učeći na iskustvima drugih te prateći primjere dobre prakse i potrebe korisnika knjižnice.

\section{Zaključak}

Prateći promjene u znanstvenom okruženju te nove potrebe i zahtjeve svojih korisnika, visokoškolske knjižnice uvode i razvijaju nove usluge koje se odnose na istraživačke podatke. Na taj način knjižnice povećavaju izglede ustanove za dobivanje sredstava za projekte, a sebi osiguravaju status relevantnog i važnog čimbenika u istraživačkom procesu.

Usluge koje se tiču podataka u velikoj se mjeri uklapaju u tradicionalnu ulogu knjižnice te djelomice predstavljaju proširenje uobičajenih zadaća informacijske službe na podatke kao vrstu građe (npr. tematska pretraživanja, informacije o citiranju). Ipak većina tih usluga zahtijeva nove vještine i znanja knjižničara, posebno u odnosu na softver i web-alate koji se koriste za pohranu i pronalaženje setova podataka, poznavanje istraživačke metodologije i alata za obradu podataka.

Neke od prepreka za uvođenje te vrste usluga jesu: financijske, organizacijske, nedostatak edukacije za knjižničare o upravljanju podacima zbog specifičnosti podataka u odnosu na tradicionalnu knjižničnu građu te razlike u potrebama istraživača i studenata s obzirom na područja znanosti kojima se bave. Stoga je za razvoj usluga veznih uz istraživačke podatke u knjižnicama važan timski rad u koji će biti uključeni knjižničari sa svojim specifičnim znanjima i vještinama. Također je neophodna suradnja unutar ustanove s drugim službama koje pružaju podršku istraživačima, a ključna je suradnja s ostalim ustanovama koje se bave istraživačkim podacima i transfer znanja s obzirom na važne komponente tih usluga - hardverske, softverske i edukacijske. Posebno se to odnosi na već etablirane arhive podataka s dugom tradicijom poslovanja i pružanja usluga koje se tiču istraživačkih podataka. 


\section{LITERATURA}

Association of College and Research Libraries. Value of academic libraries: a comprehensive research review and report. Researched by Megan Oakleaf. Chicago: Association of College and Research Libraries, 2010. [citirano 2018-06-10]. Dostupno na: http://www.ala.org/acrl/sites/ala.org.acrl/files/content/issues/value/val_report. pdf.

Association of European Research Libraries. Ten recommendations for libraries to get started with research data management: final report of the LIBER working group on e-science/research data management. 2012. [citirano: 2018-04-06]. Dostupno na: http://libereurope.eu/wp-content/uploads/The $\% 20$ research $\% 20$ data $\% 20$ group $\% 20$ 2012\%20v7\%20final.pdf.

Berlinska deklaracija. 2003. [citirano: 2018-04-09]. Dostupno na: http://eprints.rclis. org/4571/1/prijevod_berlinske_deklaracije.pdf.

Bethesda Statement on Open Access Publishing. 2003. [citirano: 2018-04-09]. Dostupno na: http://legacy.earlham.edu/ peters/fos/bethesda.htm.

Budapest Open Access Initiative. 2002. [citirano: 2018-04-09]. Dostupno na: http:// www.budapestopenaccessinitiative.org/read.

CESSDA ERIC. [citirano: 2018-04-09]. Dostupno na: https://www.cessda.eu/.

CESSDA ERIC. Data publishing routes. // Expert tour guide to data management. [citirano: 2018-04-06]. Dostupno na: https://www.cessda.eu/Research-Infrastructure/ Training/Expert-Tour-Guide-on-Data-Management/6.-Archive-Publish/Data-publishing-routes.

CESSDA ERIC. Expert tour guide on data management. [citirano: 2018-04-06]. Dostupno na: https://www.cessda.eu/Research-Infrastructure/Training/Expert-Tour-Guide-on-Data-Management.

CESSDA ERIC. Research data. // Expert tour guide to data management. [citirano: 2018-04-06]. Dostupno na: https:/www.cessda.eu/Research-Infrastructure/Training/Expert-Tour-Guide-on-Data-Management/1.-Plan/Research-data.

Conrad, S.; Y. Shorish; A. L. Whitmire; P. Hswe. Building professional development opportunities in data services for academic librarians. // IFLA Journal 43, 1(2017), 65-80. .DOI: http://dx.doi.org/10.1177/0340035216678237.

Cox, A. M.; M. A. Kennan; L. Lyon; S. Pinfield. Developments in research data management in academic libraries: towards an understanding of research data service maturity. // Journal of the Association for Information Science and Technology 68, 9(2017), 2182-2200. DOI: http://dx.doi.org/10.1002/asi.23781.

European Commission, Directorate-General for Research \& Innovation. H2020 programme : guidelines to the rules on open access to scientific publications and open access to research data in Horizon 2020. [citirano: 2018-04-06]. Dostupno na: 
http://ec.europa.eu/research/participants/data/ref/h2020/grants_manual/hi/oa_pilot/ h2020-hi-oa-pilot-guide_en.pdf.

Geraci, D.; J. Jacobs; C. Humphrey. Data basics: an introductory text. 2012. DOI: http:// dx.doi.org/10.7939/R3251FK8F.

Gold, A. Cyberinfrastructure, data, and libraries. Part 1: a cyberinfrastructure primer for librarians. // D-Lib Magazine 13, 9-10(2007). DOI: http://dx.doi.org/10.1045/ september20september-gold-pt1.

Gold, A. Cyberinfrastructure, data, and libraries. Part 2: libraries and the data challenge: roles and actions for libraries. // D-Lib Magazine 13, 9-10(2007). DOI: http://dx.doi. org/10.1045/september2007-gold-pt2.

Henneken, E. Unlocking and sharing data in astronomy. // Bulletin of the Association for Information Science and Technology 41, 48(2015), 40-43. [citirano: 2018-0408]. Dostupno na: https://asis.org/Bulletin/Apr-15/AprMay15_RDAP_Henneken. pdf.

Inter-university Consortium for Political and Social Research (ICPSR). [citirano: 201804-09]. Dostupno na: https://www.icpsr.umich.edu.

Linde, P.; M. Noorman; B.A. Wessels; T. Sveinsdottir. How can libraries and other academic stakeholders engage in making data open? // Information Services \& Use 34(2014), 211-219. DOI: https://dx.doi.org/10.3233/ISU-140741.

Ministarstvo znanosti, obrazovanja i sporta i AMPEU. Što je Obzor 2020? [citirano: 2018-04-06]. Dostupno na: http://www.obzor2020.hr/.

National Human Genome Research Institute. [citirano 2018-04-06]. Dostupno na: www. genome.gov.

OECD. Principles and guidelines for access to research data from public funding. OECD, 2007. [citirano: 2018-04-06]. Dostupno na: http://www.oecd.org/sti/sci-te$\mathrm{ch} / 38500813$.pdf.

OpenAire. Open research data pilot. [citirano: 2018-04-06]. Dostupno na: https://www. openaire.eu/opendatapilot.

Pampel, H.; S. Dallmeier-Tiessen. Open research data: from vision to practice. // Opening science: the evolving guide on how the Web is changing research, collaboration and scholarly publishing / S. Bartling, S. Friesike [eds]. Berlin: Springer, 2014. Str. 139-153. [citirano: 2018-04-06]. Dostupno na: http://book.openingscience.org/vision/open_research_data.html.

Rice, R.; J. Southall. The data librarian's handbook. London: Facet Publishing, 2016.

re3data. [citirano: 2018-04-06]. Dostupno na: http://www.re3data.org/.

Reeves Flores, J. Libraries and the research data management landscape. // The process of discovery: the CLIR postdoctoral fellowship program and the future of the academy / editors J.C. Maclachlan, E. A. Waraksa and C. Williford. Washington: 
CLIR, 2015. [citirano 2018-04-06]. Dostupno i na: https://www.clir.org/wp-content/ uploads/sites/9/RDM.pdf.

Tenopir, C.; R.J. Sandusky; S. Allard; B. Birch. Research data management services in academic research libraries and perception of librarians. // Library \& Information Science Research 36, 2(2014), 84-90. DOI: https://doi.org/10.1016/j. lisr.2013.11.003.

Tenopir, C., S. Talja; W. Horstmann; E. Late; D. Hughes; D. Pollock; B. Schmidt; L. Baird; R. J. Sandusky; S. Allard. Research data services in European academic research libraries. // LIBER Quarterly 27, 1(2017), 23-44. DOI: http://dx.doi.org/10.18352/ lq.10180.

Unidata: data services and tools for geoscience. [citirano: 2018-04-07]. Dostupno na: http://www.unidata.ucar.edu/data/.

Wilkinson, M. D.; M. Dumontier; I. J. Aalsbersberg; G. Appleton; M. Axton; A. Baak; $\mathrm{N}$. Blomberg, et al. The FAIR Guiding principles for scientific data management and stewardship. // Scientific Data 3(2016), 160018. DOI: http://dx.doi.org/10.1038/ sdata.2016.18.

Zenodo. [citirano: 2018-04-09]. Dostupno na: https://zenodo.org/. 